\title{
THE EXPECTED DEMOGRAPHIC INFLUENCES ON THE PROVISION OF EDUCATION SERVICES IN THE NEIGHBOURHOODS OF RIGA
}

\author{
Elina Apsite-Berina \\ University of Latvia, Faculty of Geography and Earth Sciences, Latvia \\ Juris Paiders \\ University of Latvia, Faculty of Geography and Earth Sciences, Latvia \\ Aleksandrs Dahs \\ University of Latvia, Faculty of Business, Faculty of Business, \\ Management and Economics, Latvia \\ Maris Berzins \\ University of Latvia, Faculty of Geography and Earth Sciences, Latvia
}

\begin{abstract}
This paper discusses the spatial extent of population change and provides new insights into the relationships between demographic characteristics and the provision of education services in urban neighbourhoods of Riga. Thus, our empirical evidence confirms that the provision of social infrastructure is fundamentally dependent on the nature of demographic processes. The aim of this paper is twofold: to explore the spatial extent of changes in the number of pre-school and school-aged children in Riga, and to assess how the demographic change of particular age cohorts are associated with the provision of educational establishments at the neighbourhood level. Using available statistics and based on calculations, this article reveals how the interplay between demographic and education related characteristics could be used in the analysis of particular age groups. The main findings show that educational institutions in capital city are distributed unevenly. Similarly, there is a great variety in demographic development between the urban neighbourhoods of Riga. Thus, unmatched demand for educational facilities or lacking specific types of institutions altogether create additional load in the neighbourhoods of inner-city, while increasing daily mobility of children and their parents.
\end{abstract}

Keywords: demography, educational statistics, population forecast, Riga, school network, urban neighbourhoods.

\section{Introduction}

Throughout the past decades' demographic change in Latvia and its consequences on socio-economic development has attracted growing interest in academic studies, public debate, and national policies. Since the early 1990s, Latvia along the other countries of Central and Eastern Europe experienced 
Apsite-Berina et al., 2020. The Expected Demographic Influences on the Provision of Education Services in the Neighbourhoods of Riga

sudden and simultaneous turnabouts in all the components of demographic change - fertility, mortality and international migration (Krūmiņš \& Krišjāne, 2016; Weishaupt, 2016; Fihel \& Okólski, 2019). The recent demographic processes and the post-socialist transition created unique conditions, resulting in a certain deterioration in the living standards for society and a drop in expenditure for social infrastructure (Vihalemm et al., 2017). Therefore, the share in total population and geographic distribution of particular age groups is essential in the provision of certain services. Riga, the capital and the largest city of Latvia, houses around one-third of nations nearly two million populations. The Latvian capital, similarly to other largest cities in the Central and Eastern Europe, has witnessed a process of steadily population decline (Kabisch \& Haase, 2011). Population shrinkage has contributed to changes in the age structure of the urban population. Some paradox is emerging since 2011, as both the elderly and the child share have been increasing at the same time (Bērziñš, 2019). Thus, the Riga City Council has to take into account the demand for adequate social infrastructure and to ensure coverage of the essential services and facilities among others also efficient school network provision. According to the responsibility of Riga City Council, they should provide access to pre-school education, primary education, secondary or vocational education to all children. Access also include choice of interest education, support extracurricular activities. The infrastructure of educational institutions in the city of Riga consists of the network supported by the state, municipality and private institutions. Nevertheless, it has been stated that school network in Riga require optimisation (RD IKSD, 2020).

The aim of this paper is twofold: to explore the spatial extent of changes in the number of pre-school and school-aged children in Riga, and to assess how the demographic change of particular age cohorts are associated with the provision of educational establishments at the neighbourhood level. Using available statistics and based on calculations, this article reveals how the interplay between demographic and education related characteristics could be used in the analysis of particular age groups.

\section{Previous studies and literature review}

Demographic change affects societal development at various levels and social infrastructure. Thus, touching upon school network when studying the distribution of children in a city (Weishaupt, 2016). A recent study on population modelling in the context of urban land use shifts in Europe recognise the importance of composition and dynamics of the population in the projection of the population structure (Terama et al., 2019). Mayaud et al. (2019) have studied accessibility to essential services among most vulnerable groups such as children and youth and seniors. A recent study by Langfor et al. (2019) addresses the 
urgent need to map the observed picture of the institutional network at early childhood age. The situation in Latvia highlights the importance of research-based policymaking and increase of awareness of demographic issues (Rivza \& Jermolajeva, 2018). Previous demographic research as the main challenges indicated the need to overcome the population decline in Riga. As possible tools to stabilise inevitable population decrease and regular age structure update suggested to eliminate the causes of emigration and increase the number of children by supporting families (Eglīte et al., 2012; Krūmiṇš \& Bērziñš, 2019). Usually much effort is expended by researchers, governments and municipalities in predicting the future of the population under a given set of assumptions. This is essential for planning the health provision and improving people's access to education, in delivering future retail services and in adaption of pension system to current demographic conditions (Wilson \& Rees, 2005).

\section{Methodological approach}

The interest in population forecasts has always attracted the attention of wide public. Simultaneously the number of relevant studies has increased in recent years (Krūmiņ̌̌ \& Bērziņš, 2019). This reflects the growing availability of statistical data to be assessed. However, the geographical coverage and the available time series are still insufficient for comprehensive population projections. In this study we used an extrapolation time series method to predict the number of pre-school and school-aged children in each neighbourhood of Riga. Extrapolative time series method allows to produce prediction intervals that encompass variability from the past change (Booth, 2006). Mathematical calculations were used to forecast place-specific changes of pre-school (0-6) and school-aged (7-14) children, based on previous studies (Krūmiņš \& Bērziṇš, 2019) and past data analysis of time series (2016-2019) coefficients on the changes in fertility, mortality and net migration rates. The greatest uncertainties concern the net migration component of the current forecast and the time coverage of the past data available for predictions. The data sets used in the calculations were derived from the database of the Central Statistical Bureau of Latvia (CSB) referring to territorial statistics or also named as experimental statistics. Subsequently the necessary fertility, mortality and net migration rates required for population forecast were calculated using these data sets from particular time series (2016-2019).

For the analysis on the provision of education services, we used education statistics available at the neighbourhood level in Riga. Information on the number of institutions of pre-school, general education, and vocational education, as well as sports facilities were accumulated from various sources (RD IKSD, 2020; RD PAD, 2020). It is also possible to predict the future demand for primary and 
Apsite-Berina et al., 2020. The Expected Demographic Influences on the Provision of Education Services in the Neighbourhoods of Riga

secondary education facilities by comparing current number of children in " $0-6$ " and in "7-14" age groups in every neighbourhood. Furthermore, using available population statistics (CSB, 2020), we calculated several demographic characteristics in order to describe the demographic conditions of a particular neighbourhood in details (see Table 1). The methodological framework includes several steps of analysis. Firstly, we present descriptive statistics of the demographic and education related characteristics used in the study. Secondly, we adopt the ranking procedure of neighbourhoods based on the overall combination of the above indicated characteristics. This allowed us to find out the trend of demographic development and the provision with educational institutions in each neighbourhood of Riga and then rank them in ascending order.

Table 1 Descriptive statistics of the demographic and education related characteristics used in the study

\begin{tabular}{|l|c|}
\hline Characteristics & Mean value \\
\hline Share (\%) of the pre-school aged (0-6) children, 20191 & 8.1 \\
\hline Change (\%) of the pre-school aged (0-6) children, 2018-2019 & 10.4 \\
\hline Share (\%) of the school aged (7-14) children, 20191 & 8.2 \\
\hline Change (\%) of the school aged (7-14) children, 2018-2019 & 8.2 \\
\hline Expected change (\%) of the pre-school aged (0-6) children, 2019-2030 & 10.9 \\
\hline Expected change (\%) of the school aged (7-14) children, 2019-2030 & 8.2 \\
\hline Crude birth rate per 1 000 inhabitants, 2018 & 11.2 \\
\hline Crude death rate per 1000 inhabitants, 2018 & 13.3 \\
\hline Net migration rate per 1000 inhabitants, 2018 & 0.9 \\
\hline Pre-school aged (0-6) children per institution of the preschool education, 2019 & 325 \\
\hline School aged (7-14) children per institution of the general education, 2019 & 411 \\
\hline School aged (7-14) children per institution of the vocational education, 2019 & 522 \\
\hline School aged (7-14) children per sport facility, 2019 & 295 \\
\hline
\end{tabular}

Note: ${ }^{1}$ at the beginning of the year.

Source: Authors' elaboration based on the data acquired from the Central Statistical Bureau of Latvia (CSB) and the Education, Culture, and Sports Department of Riga City Council (RD IKSD).

Finally, the average values of the sum of the rankings obtained due to the calculations were broken down into quartiles allowing to identify the areas with good demographic conditions and the provision of educational establishments, as well as less favourable neighbourhoods. Upper quartile (see Figure 3) means 
relatively good demographic conditions and balanced provision of educational establishments, while lower quartile represents demographic decline and/or lack of adequate services in terms of educational institutions and sports facilities available to children.

\section{The expected changes in the number of pre-school and school aged children in Riga neighbourhoods}

The expected changes in the number of the particular age groups of interest were calculated on the assumption of the demographic development trends from particular time series (2016-2019), taking into account basic demographic processes (fertility, mortality and net migration). According to the expected changes, the total population of Riga will continue to decline. However, the share of pre-school and school aged children is expected to stabilize (see Figure 1), but the numbers will even slightly increase by 2030. Thus, in both age groups the predicted total number of children in each age group will comprise around 50 thousand by 2030. This indicates a very small increase in the number of preschool children and approximately the same number in the school aged group.

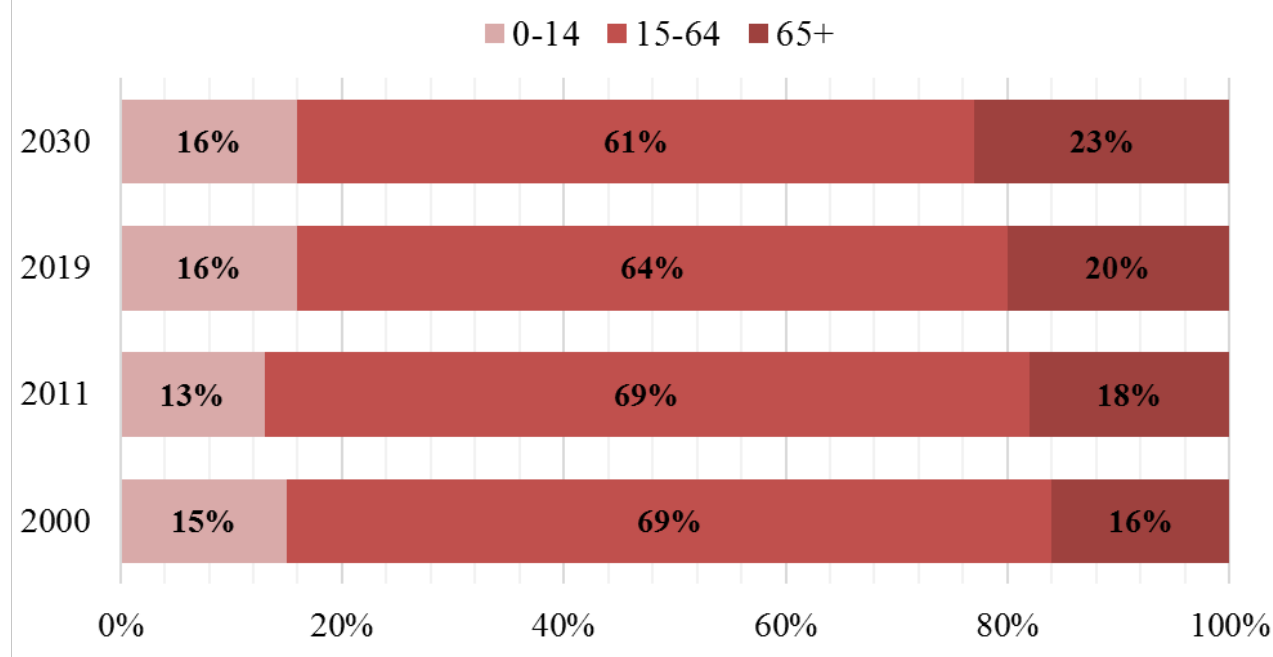

Figure 1 Estimated and expected share (\%) of main age groups in Riga (authors' elaboration based on the data acquired from the CSB; Krūmiňš \& Bērziņš, 2019)

Table 2 summarises the expected shifts in the numbers of children aged 0-6 years and 7-14. Numerous neighbourhoods are showing a steady to moderate decline. At the same time also moderate to high grows of the number of children can be expected, pointing to the need to reassess the school network. Neighbourhoods not mentioned in Table will hold a stable number of children up to six years old by 2030 could be stable and not differ from the one observed in 2019 by more than $5 \%$. 
Apsite-Berina et al., 2020. The Expected Demographic Influences on the Provision of Education Services in the Neighbourhoods of Riga

Table 2 Projection results of the preschool aged (0-6) and school aged (7-14) children by the neighbourhoods of Riga for 2019-2030

\begin{tabular}{|c|c|c|c|c|}
\hline $\begin{array}{l}\text { Strong decline } \\
\text { (over 15\%) }\end{array}$ & $\begin{array}{l}\text { Moderate decline } \\
\text { (up to } 15 \% \text { ) }\end{array}$ & $\begin{array}{l}\text { Age } \\
\text { group }\end{array}$ & $\begin{array}{l}\text { Moderate growth } \\
\text { (up to 15\%) }\end{array}$ & $\begin{array}{l}\text { High growth } \\
\text { (over 15\%) }\end{array}$ \\
\hline $\begin{array}{l}\text { Brasa } \\
\text { Dreiliņi } \\
\text { Mangaḷsala } \\
\text { Salas } \\
\text { Spilve }\end{array}$ & 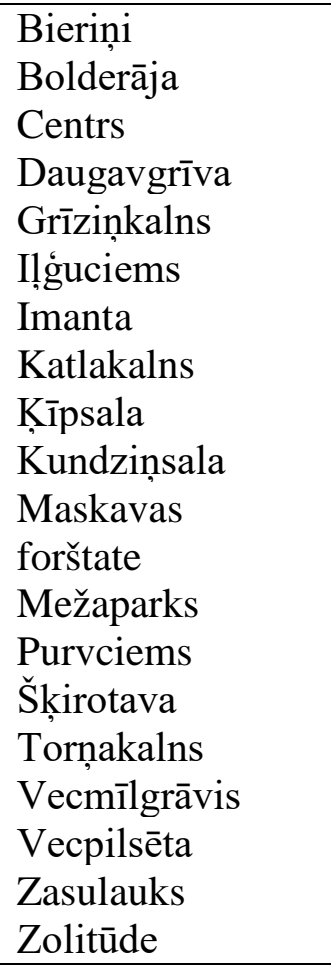 & $\begin{array}{l}0-6 \\
\text { years }\end{array}$ & $\begin{array}{l}\text { Āgenskalns } \\
\text { Avoti } \\
\text { Brekši } \\
\text { Dārzciems } \\
\text { Dzirciems } \\
\text { Jugla } \\
\text { Kengarags } \\
\text { Mežciems } \\
\text { Pētersala/Andrejsala } \\
\text { Pḷavnieki } \\
\text { Pleskodāle } \\
\text { Rumbula } \\
\text { Šampēteris } \\
\text { Sarkandaugava } \\
\text { Suži } \\
\text { Teika } \\
\text { Trīsciems } \\
\text { Vecdaugava } \\
\text { Ziepniekkalns }\end{array}$ & $\begin{array}{l}\text { Atgāzene } \\
\text { Beberbeķi } \\
\text { Berǵi } \\
\text { Bišumuiža } \\
\text { Bukulti } \\
\text { Buḷıi } \\
\text { Čiekurkalns } \\
\text { Dārziṇi } \\
\text { Jaunciems } \\
\text { Kleisti } \\
\text { Mīlgrāvis } \\
\text { Mūkupurvs } \\
\text { Skanste } \\
\text { Vecāḳi } \\
\text { Voleri }\end{array}$ \\
\hline $\begin{array}{l}\text { Strong decline } \\
\text { (over 15\%) }\end{array}$ & $\begin{array}{l}\text { Moderate decline } \\
\text { (up to } 15 \% \text { ) }\end{array}$ & $\begin{array}{l}\text { Age } \\
\text { group }\end{array}$ & $\begin{array}{l}\text { Moderate growth } \\
\text { (up to } 15 \% \text { ) }\end{array}$ & $\begin{array}{l}\text { High growth } \\
\text { (over 15\%) }\end{array}$ \\
\hline $\begin{array}{l}\text { Beberbeķi } \\
\text { Bieriņi } \\
\text { Bolderāja } \\
\text { Daugavgrīva } \\
\text { Dreiliņi } \\
\text { Kundziņsala } \\
\text { Mangạ̦sala } \\
\text { Mežaparks } \\
\text { Šķirotava } \\
\text { Spilve } \\
\text { Suži }\end{array}$ & $\begin{array}{l}\text { Buḷli } \\
\text { Centrs } \\
\text { Dzirciems } \\
\text { Iḷguciems } \\
\text { Imanta } \\
\text { K̦engarags } \\
\text { Ķīpsala } \\
\text { Maskavas } \\
\text { forštate } \\
\text { Pleskodāle } \\
\text { Purvciems } \\
\text { Sarkandaugava } \\
\text { Torṇakalns } \\
\text { Vecmīlgrāvis } \\
\text { Zasulauks } \\
\text { Zolitūde }\end{array}$ & $\begin{array}{l}7-14 \\
\text { years }\end{array}$ & $\begin{array}{l}\text { Āgenskalns } \\
\text { Atgāzene } \\
\text { Avoti } \\
\text { Brasa } \\
\text { Bukulti } \\
\text { Dārzciems } \\
\text { Grīziņkalns } \\
\text { Jaunciems } \\
\text { Jugla } \\
\text { Mežciems } \\
\text { Mīlgrāvis } \\
\text { Pētersala/Andrejsala } \\
\text { Plavnieki } \\
\text { Salas } \\
\text { Teika } \\
\text { Trīsciems } \\
\text { Vecpilsēta } \\
\text { Ziepniekkalns }\end{array}$ & $\begin{array}{l}\text { Berği } \\
\text { Bišumuiža } \\
\text { Brekši } \\
\text { Čiekurkalns } \\
\text { Dārziņi } \\
\text { Katlakalns } \\
\text { Kleisti } \\
\text { Mūkupurvs } \\
\text { Rumbula } \\
\text { Šampēteris } \\
\text { Skanste } \\
\text { Vecāḳi } \\
\text { Vecdaugava } \\
\text { Voleri }\end{array}$ \\
\hline
\end{tabular}

Source: Authors' elaboration based on the data acquired from the Central Statistical Bureau of Latvia (CSB). 


\section{The current provision of education services in the neighbourhoods of Riga}

The following maps below (see Figure 2) show the number and distribution of institutions of the pre-school education and institutions of the general education, vocational education, and sports facilities in Riga. Both maps indicate an uneven distribution of educational facilities available in each neighbourhood. The smallest spatial variance is observed in pre-school institutions, while variance for schools and vocational schools is higher. Small in terms of population and some outer-city neighbourhoods mostly enjoy relatively low demand for schools and other facilities. Although understandably, vocational schools are mostly situated in the inner- city, there is an apparent lack of such institutions in densely populated neighbourhoods with high shares of children in 7-14 age group. The neighbourhoods with unmatched demand for educational facilities or lacking specific types of institutions altogether create additional load on their adjacent areas and central parts of the city while increasing daily internal mobility of children and their parents.
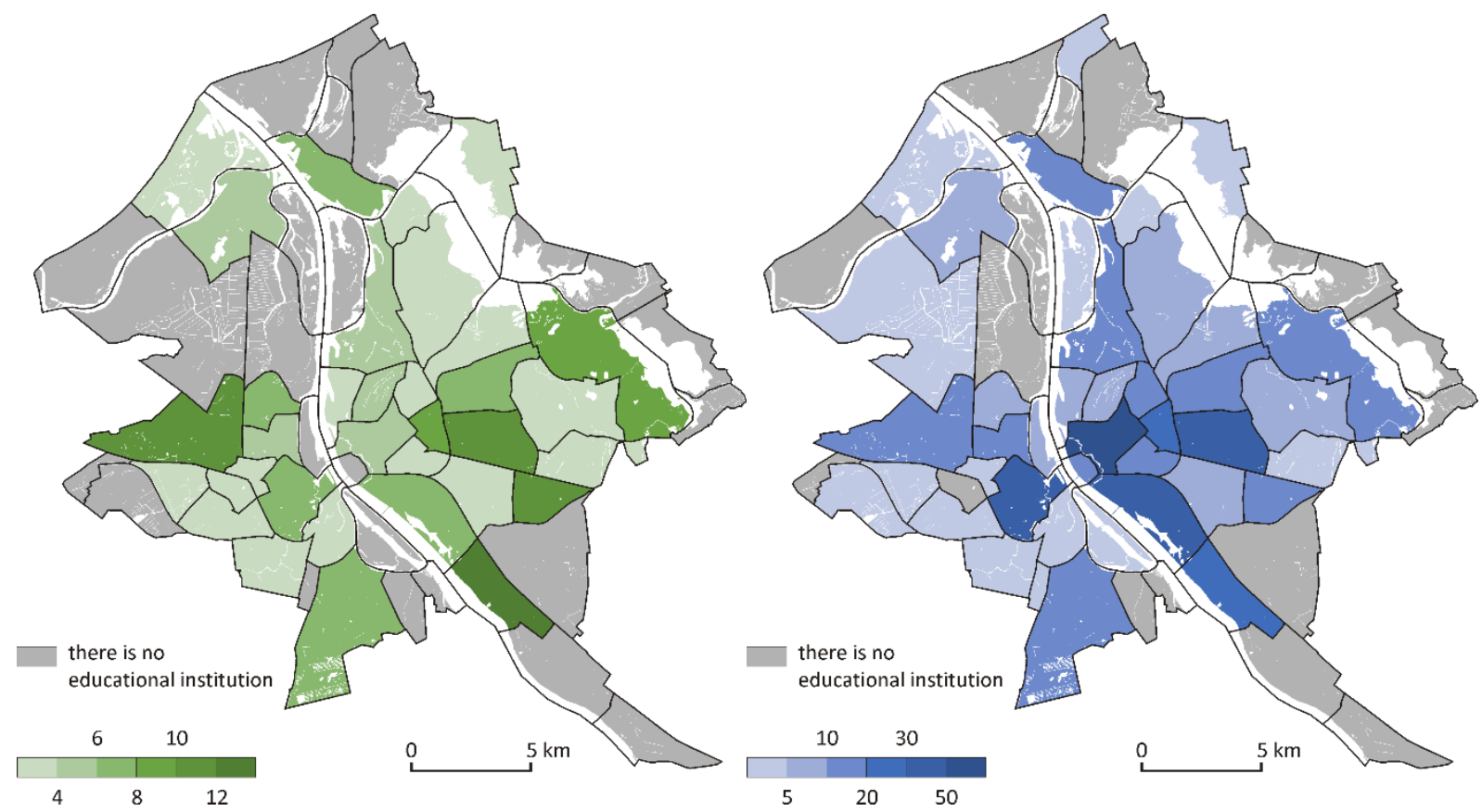

Figure 2 Number and distribution of institutions of the preschool education (on the left) and institutions of the general education, vocational education, and sports facilities (on the right) in the neighbourhoods of Riga (authors' elaboration based on the data acquired from the Education, Culture, and Sports Department of Riga City Council, RD IKSD))

When looking at regular schools, the situation is similar. With some exceptions, most neighbourhoods currently dealing with higher demand for primary schools will see a gradual reduction in the number of school-age children 
Apsite-Berina et al., 2020. The Expected Demographic Influences on the Provision of Education Services in the Neighbourhoods of Riga

within the next few years when relatively smaller pre-school groups reach primary school age.

The results of the neighbourhood ranking based on the overall combination of the demographic and education related characteristics confirms that the provision of education services in terms of different kind of institutions are distributed unevenly within the city (see Figure 3). It is also evident that according to the current development trend, educational infrastructure in Riga neighbourhoods is fragmented. Thus, the unmatched demand for educational facilities or lacking specific types of institutions altogether create additional load on their adjacent areas and central parts of the city, while increasing daily internal mobility of children and their parents. According to the obtained results of ranking procedure the neighbourhoods in upper quartile (Q1) display balanced distribution of demographic and education-related characteristics, which means that demographic trends are consistent with the available infrastructure of educational institutions. These neighbourhoods are mostly located in the innercity, as well as some outer-city neighbourhoods where demographic characteristics appeared to be very good (e.g. Bullıi, Vecāḳi, Kleisti, Dārziṇi, Atgāzene).

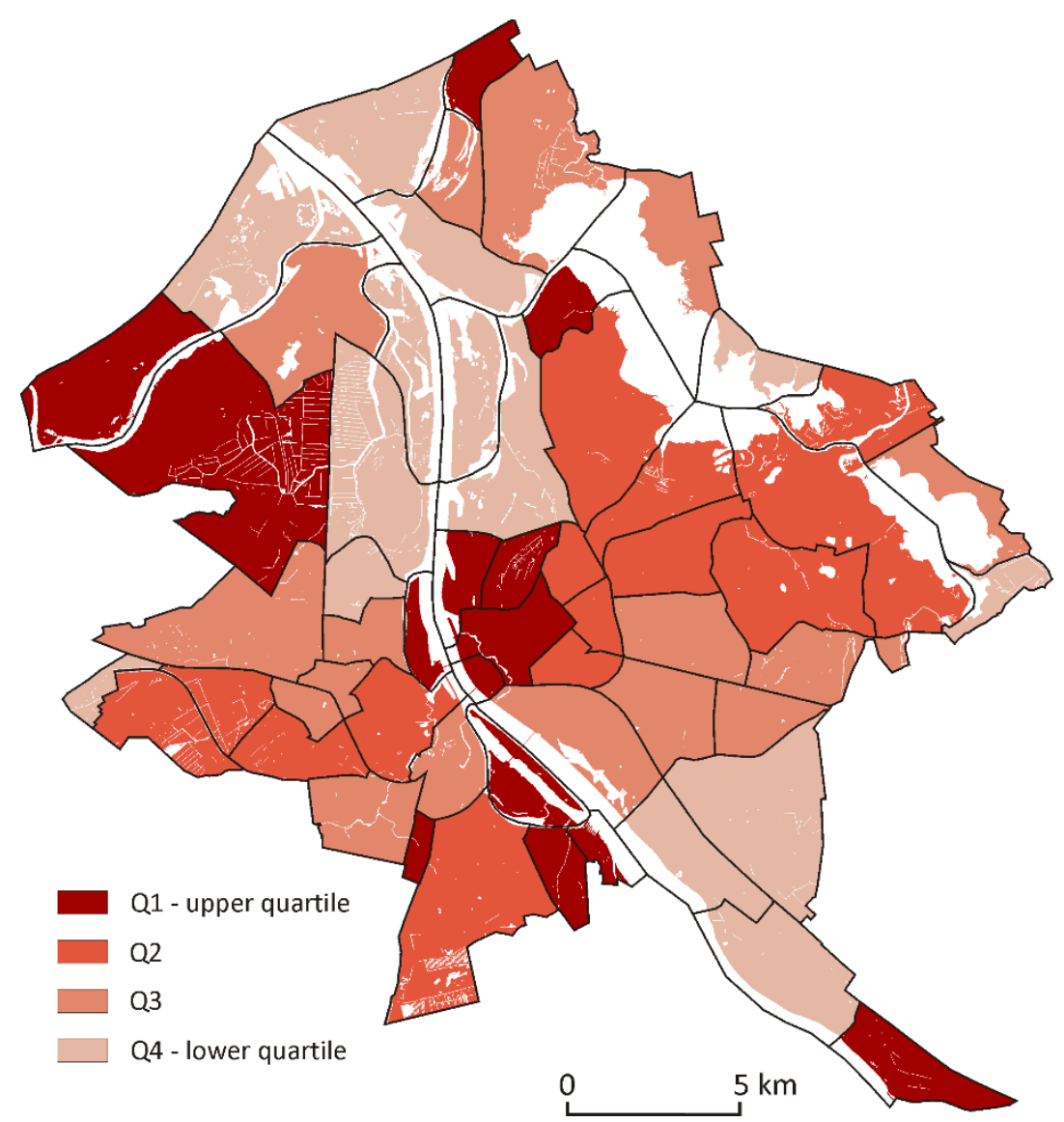

Figure 3 The results of the overall ranking of the demographic and education related characteristics used in the study (authors' elaboration based on the data acquired from the Education, Culture, and Sports Department of Riga City Council, RD IKSD) 
At the same time the Figure 3 indicates that urban neighbourhoods in the both lower quartiles (Q3 and Q4) represent areas with a not balanced distribution of education services in terms of institutions and demographic trends. Consistent planning approach for sustainable societal and territorial development should be regarded in those urban neighbourhoods with a numerous population (e.g. Ķengarags, Iḷguciems, Dzirciems, Sarkandaugava, Pḷavnieki, Purvciems, Imanta, Vecmilgrāvis and others).

\section{Conclusions}

We summarise the conclusions of our study of the expected demographic influences on the provision of education services in the neighbourhoods of Riga. Spatial analysis on demographic change and provision of education services is essential for societal development. This is particularly noteworthy in the context of depopulation trends in Latvia and planning the future provision of social infrastructure. With this paper we explore the spatial extent of changes in the number of pre-school and school-aged children in Riga by assessing the demographic change of particular age cohort's association with the educational establishments at the neighbourhood level. A clear distinction between neighbourhoods can be seen from the available data. In some cases, pre-school age group significantly outnumbers the 7-14 age group, indicating a potentially growing demand for primary and secondary schools, as well as for associated vocational and sports facilities in the next decade. Neighbourhoods with unmatched demand for educational facilities or lacking specific types of institutions altogether create additional load on their adjacent areas and central parts of the city, while increasing daily internal mobility of children and their parents.

\section{Acknowledgements}

This work was supported by the ERDF grant 1.1.1.2/VIAA/1/16/184 and National Research Program Project grant number VPP-IZM-2018/1-0015.

\section{References}

Central statistics bureau of Latvia (CSB). (2020). Database tables RIG010 \& RIG050. Retrieved from https://www.csb.gov.lv/lv/statistika/db

Bērziņš, A. (2019). Iedzīvotāju sastāva novecošana. Krūmiņš, J., Krišjāne, Z. (zin.red.) Tautas ataudze Latvijā un sabiedrības atjaunošanas izaicinājumi. LU Akadēmiskais apgāds, Rìga.

Booth, H. (2006). Demographic forecasting: 1980 to 2005 in review. International journal of forecasting, 22(3), 547-581. 
Apsite-Berina et al., 2020. The Expected Demographic Influences on the Provision of Education Services in the Neighbourhoods of Riga

Eglīte, P., Ivbulis, B., \& Gṇedovska I. (2012). Demogrāfiskās prognozes Rīgā un Pierīgā. Pieejams http://www.sus.lv/sites/default/files/media/faili/demografiskas_prognozes_ riga_un_pieriga_rd_lza_2012.pdf

Fihel, A., \& Okólski, M. (2019). Demographic change and challenge. In Gorzelak, G. (Ed.), Social and Economic Development in Central and Eastern Europe: Stability and Change after 1990. Routledge, London and New York, 124-158.

Kabisch, N., \& Haase, D. (2011). Diversifying European agglomerations: evidence of urban population trends for the 21st century. Population, space and place, 17(3), 236-253.

Krūmiņš, J., \& Krišjāne, Z. (2016). Demogrāfiskā attīstība Latvijā: problēmas un izaicinājumi. Latvijas Zinātņu Akadēmijas Vēstis "A" daḷa, 70(3), 40-50.

Krūmiṇšs, J., \& Bērziņšs, A. (2019). Demogrāfiskās attīstības vērtējumi un prognozes. Krūmiņšs, J., Krišjāne, Z. (zin.red.) Tautas ataudze Latvijā un sabiedrības atjaunošanas izaicinājumi. LU Akadēmiskais apgāds, Rīga.

Krumins, J. et al. (2017). Demographic implications of the recent regional and cohesion policy developments in Latvia. New Challenges of Economic and Business Development-2017 Digital Economy, 288.

Langford, M., Higgs, G., \& Dallimore, D.J. (2019). Investigating spatial variations in access to childcare provision using network-based Geographic Information System models. Social Policy \& Administration, 53(5), 661-677.

Mayaud, J.R., Tran, M., Pereira, R.H., \& Nuttall, R. (2019). Future access to essential services in a growing smart city: The case of Surrey, British Columbia. Computers, Environment and Urban Systems, 73, 1-15.

Rīgas domes Izglītības, kultūras un sporta departaments (RD IKSD), 2020. Iestāžu katalogs. Pieejams http://katalogs-iksd.riga.lv/lv/sakums

Rīgas domes Pilsētas attīstības departaments (RDPAD), 2020, projekts "Rīgas apkaimes". Pieejams https://apkaimes.lv/

Rivza, B., \& Jermolajeva, E. (2018). Beyond a century. The smart Latvia. The national research programme EKOSOC-LV "Economic transformation, smart growth, governance and legal framework for the state and society for sustainable development-a new approach to the creation of a sustainable learning community”. Riga, Latvian Academy of Sciences, 416.

Terama, E., Clarke, E., Rounsevell, M.D., Fronzek, S., \& Carter, T.R. (2019). Modelling population structure in the context of urban land use change in Europe. Regional environmental change, 19(3), 667-677.

Vihalemm, P., Masso, A., \& Opermann, S. (Eds.). (2017). The Routledge International Handbook of European Social Transformations. Routledge.

Weishaupt, H. (2016). How Demographic Change Affects Education? HERJ Hungarian Educational Research Journal, 6(3), 84-94.

Wilson, T., \& Rees, P. (2005). Recent developments in population projection methodology: A review. Population, Space and Place, 11(5), 337-360. 